\title{
TEXTURE CHARACTERISTICS OF 1235 ALUMINUM ALLOY AFTER ROLLING
}

\author{
ZNAČILNOSTI TEKSTURE ALUMINIJEVE ZLITINE 1235 , \\ NASTALE MED VALJANJEM
}

\author{
Wenduan Yan $^{1 *}$, Gaosheng $\mathrm{Fu}^{2,3}$, Hongling $\mathrm{Chen}^{2}$, Lili Song ${ }^{2,3}$, Wei Liu ${ }^{1}$ \\ ${ }^{1}$ Minnan University of Science and Technology, Fujian Key Laboratory of Industrial Robot Control and Rapid Tooling, No. 1 Xueyuan Road, \\ Shishi City, 362700 Quanzhou, Fujian, China \\ ${ }^{2}$ Fuzhou University, College of Materials Science and Engineering, No. 2 Xueyuan Road, Minhou County, 350108 Fuzhou, Fujian, China \\ ${ }^{3}$ Ningde Vocational and Technical College, No. 232 Futai Road, Fuan City, 355000 Ningde, Fujian, China \\ Prejem rokopisa - received: 2018-09-08; sprejem za objavo - accepted for publication: 2019-06-27
}

doi:10.17222/mit.2018.195

Texture characteristics of the 1235 aluminum alloy at different rolling-deformation levels were studied with EBSD. The effects of hot rolling, cold rolling and plastic deformation on the ODF and texture components of the material were studied as well. The main textures of the hot-rolled material were the cube texture and the R texture. The greater was the deformation of the material, the stronger was the texture. The recrystallization texture of the $90-\%$ hot-rolled alloy was stronger than that of the material after $50-\%$ hot rolling. The R texture was the main texture of the 50-\% hot-rolled material, but it changed into the cube texture after $90-\%$ hot rolling. Recrystallization was obvious during hot rolling. The 90-\% cold-rolled material showed typical copper-texture characteristics, and work hardening was notable.

Keywords: 1235 aluminum alloy, EBSD, ODF, texture, rolling

Avtorji članka so z metodo uklona povratno sipanih elektronov (EBSD) študirali lastnosti tekstur nastalih med valjanjem Al zlitine 1235 pri različnih stopnjah deformacije. Prav tako so ugotavljali vpliv vročega in hladnega valjanja ter plastične deformacije na orientacijsko porazdelitveno funkcijo (ODF) in komponente teksture materiala. Glavni teksturi, nastali med vročim valjanjem, sta bili Cubova in R tekstura. Večja kot je bila stopnja deformacije materiala, močnejša je bila tekstura. Rekristalizacija teksture $90 \%$ vroče valjane zlitine, je bila močnejša kot pri $50 \%$ vroče valjanem materialu. Pri $50 \%$ vroče valjanem materialu je prevladovala $\mathrm{R}$ tekstura, medtem ko je pri $90 \%$ valjanem materialu prevladovala Cubova tekstura. Rekristalizacija je očitno potekala med vročim valjanjem. Material, ki je bil $90 \%$ hladno valjan, je kazal tipično strukturo bakra in deformacijska utrditev je bila očitna.

Ključne besede: Al zlitina 1235, EBSD, ODF, tekstura, valjanje

\section{INTRODUCTION}

The 1235 aluminum alloy is a kind of pure aluminum, widely used in packaging, electrical engineering, construction and so on. It can be processed into aluminum strips with a thickness of less than $0.2 \mathrm{~mm}$. However, cracks and other defects usually arise in an alloy during rolling. The study of the texture is an effective way for improving the structure of a material and the production yield. ${ }^{1-3}$ During the rolling of a material, the deformation behavior varies due to the difference in the grain orientation and the distribution of grain orientation. ${ }^{4,5}$ The study of the texture of an alloy after rolling can reflect the deformation properties of the material. Election backscatter diffraction (EBSD) is a powerful way for a rapid and accurate crystal-orientation measurement. It is mainly used for orientation measurement, texture analysis, phase identification, strain and grain-size measurement, providing us with a powerful way for an aluminum-texture study. ${ }^{6-9}$ In view of the characteristics of rolling in the production of aluminum

*Corresponding author's e-mail:

yanwenduan@163.com (Wenduan Yan) foil, the 1235 aluminum alloy is processed using hot rolling and subsequent cold rolling. The distribution and strength of the texture are shown by the orientation-distribution function (ODF), and the deformation mechanism of a polycrystalline aggregate is deduced at the same time. Studying the ODF and texture characteristics of a material during rolling is of theoretical significance and practical value for a rolling analysis and design.

\section{EXPERIMENTAL PART}

The 1235 aluminum alloy with a 99.35 w/\% Al content was chosen in this study. The material used in this investigation was melted using highly efficient purification, ${ }^{10}$ and the percentage of the inclusions tested with flux irrigation was $0.051 \%$. Ingots were treated with homogenization annealing at the annealing temperature of $560{ }^{\circ} \mathrm{C}$ and holding time of $13 \mathrm{~h}$, followed by and air-cooling. ${ }^{11}$ The 1235 aluminum alloy was machined to dimensions of $(270 \times 132 \times 42) \mathrm{mm}$, and then rolled using a two high irreversible hot mill of $\Phi 250 \mathrm{~mm}$ $\times 350 \mathrm{~mm}$ at the aluminum plate's temperature of $450{ }^{\circ} \mathrm{C}$. Four-pass hot rolling with an interval time of 
less than $20 \mathrm{~s}$ was used in the test. The plate was sequentially rolled with deformation degrees of $(35,50$, 75 and 90) \%. Four-pass cold rolling was used after hot rolling. The aluminum sheet was sequentially rolled with deformation degrees of $(33,60,75$ and 90$) \% .{ }^{11-13}$ The thickness of the aluminum sheet was $5 \mathrm{~mm}$ after the four-pass hot rolling, and $0.5 \mathrm{~mm}$ after the four-pass cold rolling.

Samples were cut out after each pass of the rolling. Hot-rolled specimens were cut out from the longitudinal section with a direction parallel to the compression direction with WEDM using DK7255 and were processed into thin slices. Thin slices with a thickness between $0.1 \mathrm{~mm}$ and $0.2 \mathrm{~mm}$ after grinding and mechanical polishing, including cold-rolled slices, were made into film samples using a magnetic-drive doublejet thinning device of the MTP-1A type; the film samples were not penetrated. The electrolyte in the device was composed of $5 \% \mathrm{HClO}_{3}$ and $95 \%$ ethyl alcohol. EBSD experiments were carried out using JSM6500F-type
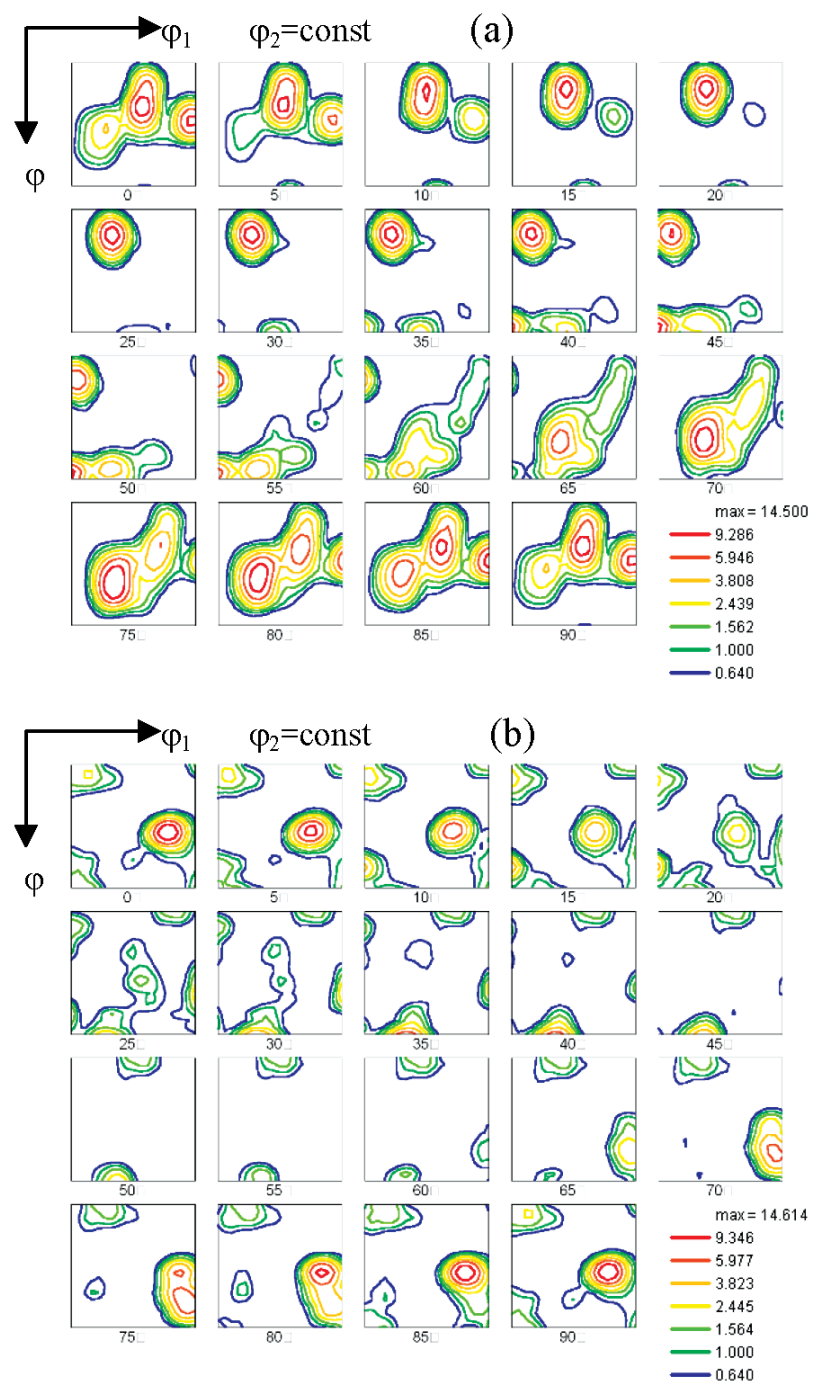

Figure 1: ODF of 1235 aluminum alloy after hot rolling: a) 50-\% hot rolling, b) $90-\%$ hot rolling field-emission scanning electron microscopy. An integrated analytical system of EDAX CENESIS 7000 EDS-PEGASIS 7000 OIM was also used with EBSD. Test parameters were as follows: an accelerating voltage of 15.0-20.0 KV, a scanning step length of 0.5-1.5 $\mu \mathrm{m}$, an amplification time of 200-2000 s and a scanning area of $(350 \times 400 \times 400) \mu \mathrm{m} .{ }^{14,15}$ An electron backscatter diffraction pattern (EBSP) was obtained then. The TSL-OIM system was used for the examination and analysis of the microcrystal orientation and texture, including the noise reduction with EBSD images. Accordingly, it was possible to obtain the orientation-distribution function (ODF) and texture-imaging information required for the study.

\section{RESULTS AND DISCUSSION}

\subsection{ODF analysis}

The ODF of the 1235 aluminum alloy after different hot-rolling deformations at $450{ }^{\circ} \mathrm{C}$ is shown in Figure 1. The corresponding analysis of orientation line $\alpha$ and orientation line $\beta$ is shown in Figure 2.

The peak of the orientation-distribution density, $f_{\max }(\mathrm{g})$, ranged from 14.500 to 14.614 as shown in Figure 1. The increase in the amplitude with the increase in the hot-rolling deformation was small. The deformation had no significant effect on the orientation-distributiondensity level during hot rolling. From Figure 2, it can be seen that the change in the grain orientation is simplified
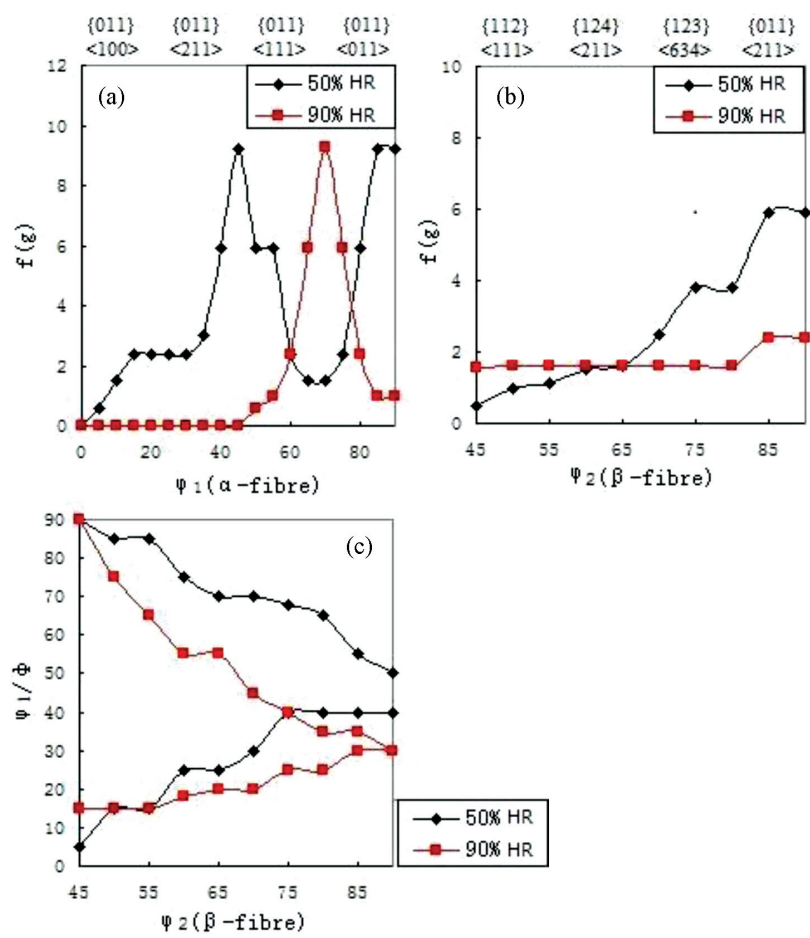

Figure 2: Orientation-line distribution of 1235 aluminum alloy after hot rolling (HR): a) orientation line $\alpha, \mathrm{b}$ ) orientation line $\beta, \mathrm{c}$ ) location of orientation line $\beta$ in the orientation space 


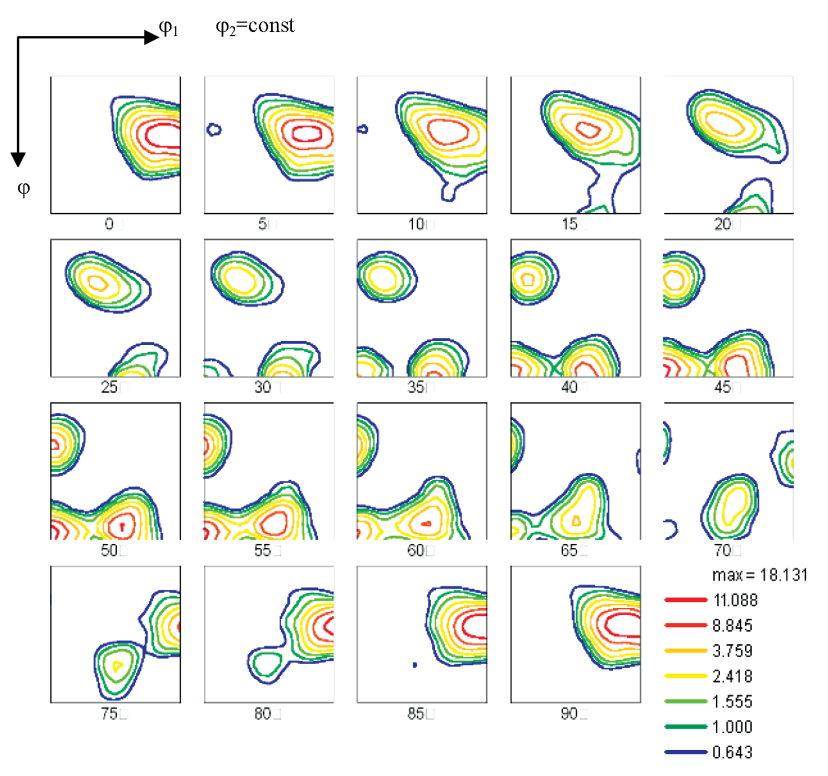

Figure 3: ODF of 90-\% cold-rolled 1235 aluminum alloy

to a few orientation lines. The texture orientation-distribution density $f(\mathrm{~g})$ extended along orientation line $\alpha$ and orientation line $\beta$ at a large rolling deformation. $\mathrm{R}$ texture $\{124\}<211>$ and brass texture $\{011\}<211>$ were stronger in the 50-\% hot-rolled aluminum alloy. However, R texture $\{124\}<211>$ and cube texture $\{001\}$ $<100>$ were stronger in the $90-\%$ hot-rolled material. It was obvious that the recrystallization texture at the deformation of $90 \%$ was stronger than that of the 50-\% deformation. Due to the shearing deformation generated from the sheet surface because of the rolling friction, a kind of shearing texture (rotating cube texture $\{001\}$ $<110>$ ) appeared at the same time. Recrystallization textures arose in the alloy at the 50-\% and 90-\% hot-rolling deformation. That is, the recrystallization textures appeared when the hot-rolling temperature was above the alloy's recrystallization temperature. Accordingly, the texture of the material exposed to the 90-\% hot-rolling deformation was stronger. The reason is that some recrystallization textures generated during the previous pass evolved into the rolling textures typical for lower finishing rolling temperatures. Generally, the textures of the 1235 aluminum alloy after hot rolling were composed of a recrystallization texture and rolling texture, and the total texture volume increased.

For further research on the texture evolution of aluminum foil during rolling, the 1235 aluminum alloy was processed with cold rolling after the 90-\% hot-rolling deformation. The textures of the specimens after the 90-\% cold-rolling deformation were studied. The ODF of the material after the 90-\% cold-rolling deformation is shown in Figure 3. Figure 4 shows the corresponding analysis of orientation line $\alpha$ and orientation line $\beta$.

From Figures 3 and 4, we can see that the peak of the orientation distribution density, $f_{\max }(\mathrm{g})$, for the 1235 aluminum alloy after cold rolling was bigger by a value of 18.131. The recrystallization texture was weaker while the deformation texture was stronger. As a result, brass texture $\{011\}<211>$ was stronger, but $\mathrm{R}$ texture $\{124\}<211>$ was weaker, as shown in the figure of orientation-line distribution. Anisotropy was obvious in the cold-rolled sheet. ${ }^{6,7}$

\subsection{Texture-distribution analysis}

Figure 5 shows grain-orientation images of the rolled 1235 aluminum alloy, and the noise reduction with EBSD images performed with the TSL-OIM system. Figure 6 shows the texture distribution in the alloy, and the tolerance for each texture component is 5 degrees.

In Figure 5, different colors represent different grain orientations. Different rolling conditions had obvious effects on the grain orientation. After 50-\% hot rolling, the grain orientation of the 1235 aluminum alloy within a certain range was more consistent. The shape of the grain-orientation image of the $90-\%$ hot-rolled alloy is
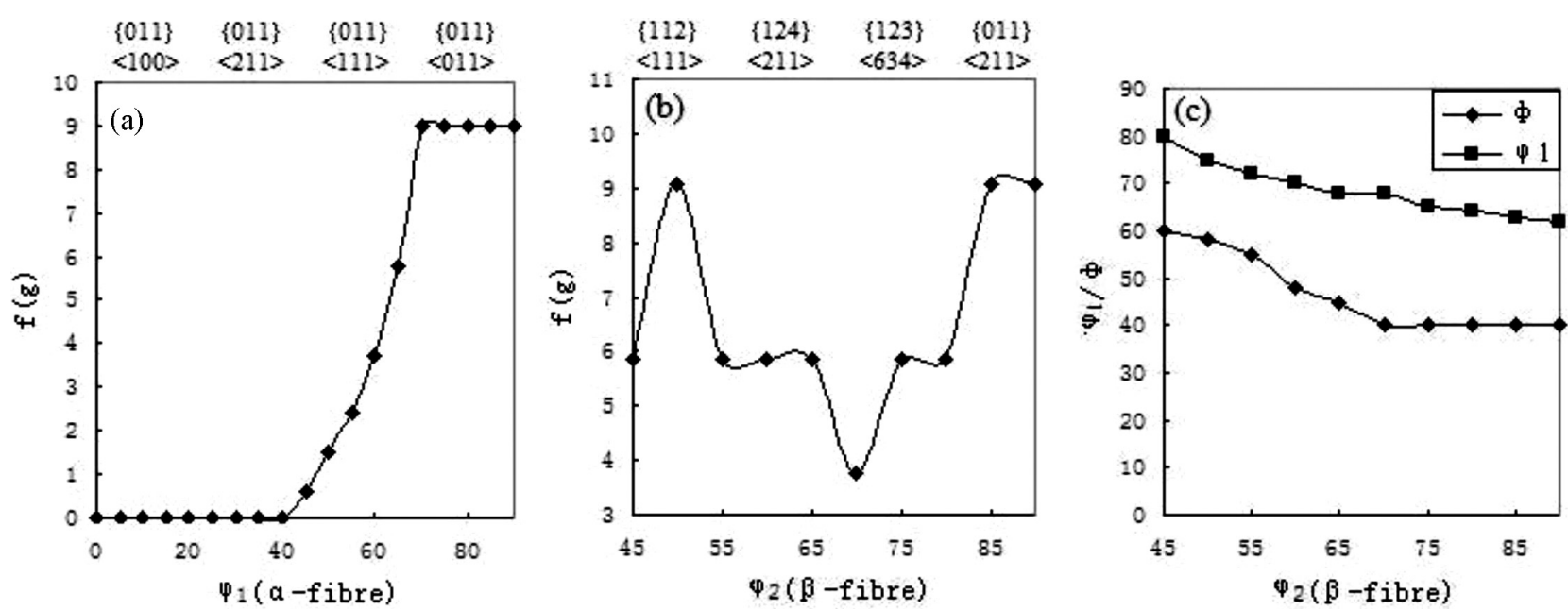

Figure 4: Orientation-line distribution of 90-\% cold-rolled 1235 aluminum alloy for: a) orientation line $\alpha$, b) orientation line $\beta$, c) location of orientation line $\beta$ in the orientation space 

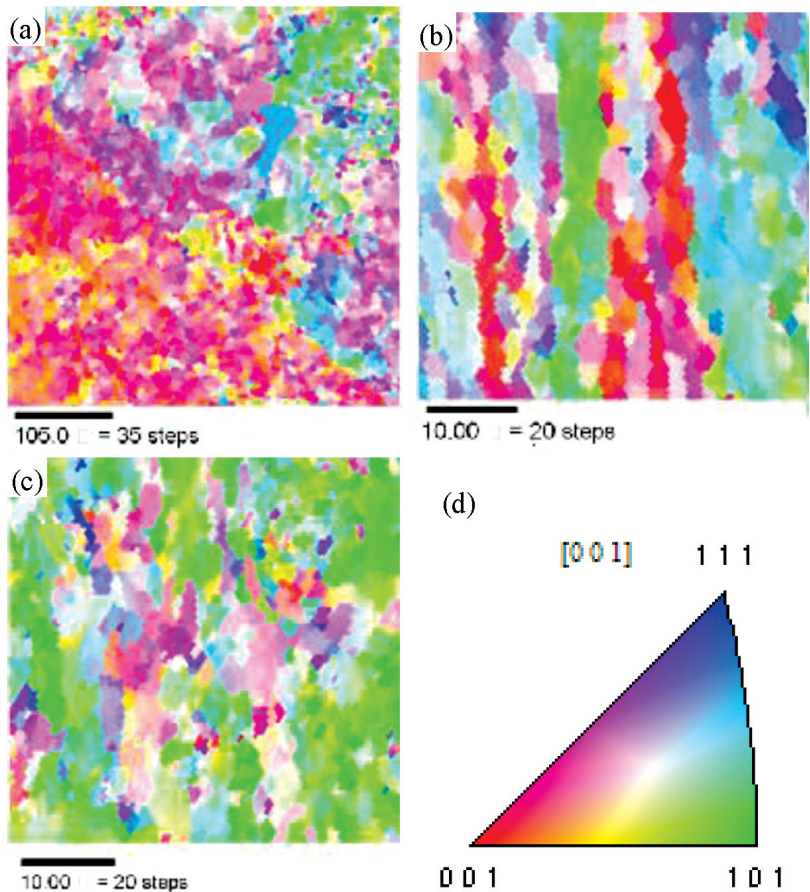

(d)

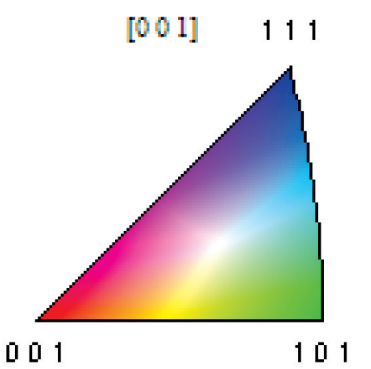

Figure 5: Grain orientation of rolled 1235 aluminum alloy for: a) 50-\% hot rolling, b) 90- $\%$ hot rolling, c) 50- $\%$ cold rolling, d) IPF for orientation distribution

fibrous. Due to the high deformation after cold rolling, the grains of the alloy were seriously distorted, and made the distribution of the grain orientation random.

In Figure 6, the main textures shown in the pictures are consistent with those of the ODFs. The main textures in the rolled alloy are cube texture $\{001\} \mathrm{d}$, brass texture
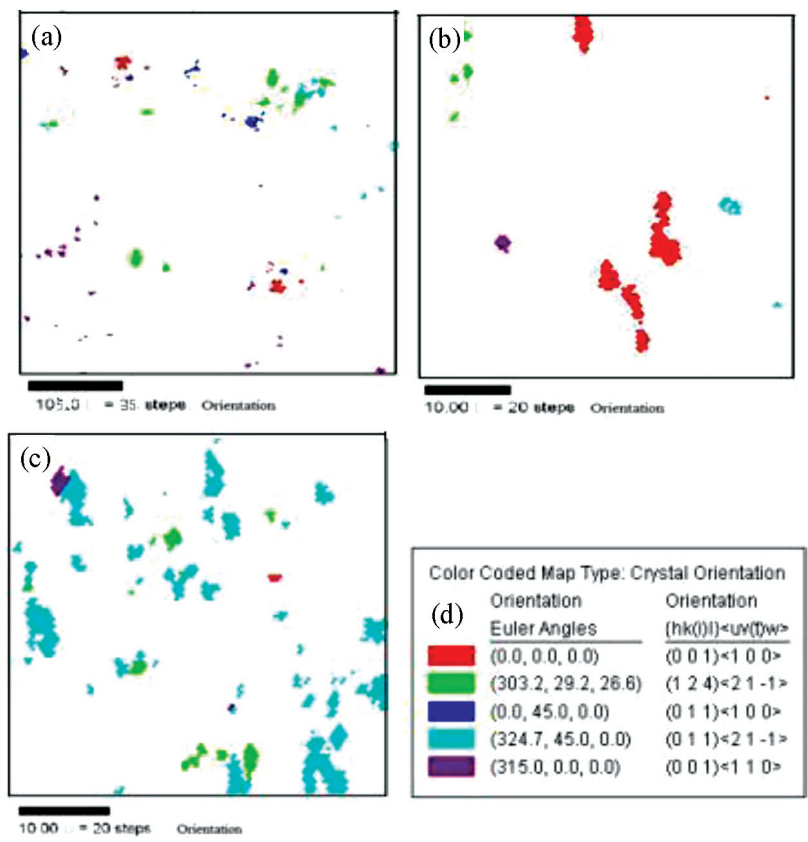

Figure 6: Texture distribution of rolled 1235 aluminum alloy for: a) $50-\%$ hot rolling, b) $90-\%$ hot rolling, c) $90-\%$ cold rolling, d) color-coded map
$\{011\}<211>$, rotated-cube texture $\{001\}<110>$, R texture $\{124\}<211>$, and brass texture $\{011\}<211>$. Besides, the main texture in the alloy after hot rolling was the recrystallization texture. After the 50-\% hot rolling, the texture image showed tiny granules with a uniform distribution. After the 90-\% hot rolling, recrystallization textures had the shape of blocks. Cube texture $\{001\} \mathrm{d}$ was the main one, while the amount of other textures was extremely low. Recrystallization was obvious during the hot rolling. After the 90-\% cold rolling, the main texture in the material was brass texture $\{011\}<211>$. Rotated-cube texture $\{001\}<110>$ and R texture $\{124\}<211>$ had a disperse distribution in the image.

The texture amount increased with the increasing rolling deformation of the 1235 aluminum alloy. The reason was that the rolling of the material caused cold-rolling deformation at a low temperature. Grains were severely deformed, generating a large amount of deformation texture. Most of the original recrystallization textures generated from hot rolling evolved into a rolling texture after the cold rolling. Normally, a large amount of rolling texture and a small amount of recrystallization texture existed after the cold rolling. The amount of the main texture components increased in the end. In the 90-\% cold-rolled 1235 aluminum alloy, the main texture was the deformation texture, showing that there was a lot of cold-deformation structure in the alloy. There was a typical copper-texture feature in the cold-rolled texture of aluminum, and the main texture was brass texture $\{011\}<211>.{ }^{13,16}$ High-fault energy of aluminum and the grain-orientation change of the aluminum plate during the cold deformation affected the texture characteristics of the material. With the increase in the deformation, the grain orientation continuously turned into brass orientation $\{011\}<211>$. The grain orientation during the rolling continually evolved into this orientation.

\section{CONCLUSIONS}

1) The main textures of the rolled 1235 aluminum alloy were the cube texture, brass texture, rotated-cube texture, $\mathrm{R}$ texture, and gross texture. The textures of the material became stronger with the increasing rolling deformation.

2) The textures of the 1235 aluminum alloy after hot rolling were composed of the recrystallization texture and rolling texture where the recrystallization texture was the main one. The recrystallization texture of the $90-\%$ hot-rolled material was stronger than that of the $50-\%$ hot-rolled material and it was notable only in the hot-rolled material.

3) Cube texture was the main texture of the 90-\% hot-rolled 1235 aluminum alloy, while brass texture was the main one of the material after cold rolling. There was a typical copper-texture feature in the cold-rolled material, and work hardening was notable. 


\section{Acknowledgements}

The authors acknowledge with gratitude the financial support received from the Fujian Natural Science Foundation (2017J01156), Cultivation Plan for Outstanding Young Scientific Research Talents of Fujian Universities, and Education and Research Project of the Fujian Education Department (JT180688), China.

\section{REFERENCES}

${ }^{1}$ M. S. Ghazani, B. Eghbali, G. Ebrahimi, Kinetics and critical conditions for initiation of dynamic recrystallization during hot compression deformation of AISI 321 austenitic stainless steel, Met. Mater. Int., 23 (2017) 5, 964-973, doi:10.1007/s 12540-017-6391-8

${ }^{2}$ T. Dursun, C. Soutis, Recent developments in advanced aircraft aluminium alloys, Materials and Design, 10 (2014), 862-871, doi:10.1016/j.matdes.2013.12.002

${ }^{3}$ A. A. Tiamiyu, A. Y. Badmos, A. G. Odeshi, J. A. Szpunar, The influence of temper condition on adiabatic shear failure of AA 2024 aluminum alloy, Materials Science \& Engineering A, 10 (2017), 492-502, doi:10.1016/j.msea.2017.10.026

${ }^{4}$ V. Y. Mehr, M. R. Toroghinejad, A. Rezaeian, Mechanical properties and microstructure evolutions of multilayered $\mathrm{Al}-\mathrm{Cu}$ composites produced by accumulative roll bonding process and subsequent annealing, Materials Science \& Engineering A, 2 (2014), 40-47, doi:10.1016/j.msea.2014.02.023

${ }^{5}$ S. C. Xu, L. D. Wang, P. T. Zhao, Evolution of texture during hot rolling of aluminum borate whisker-reinforced 6061 aluminum alloy composite, Materials Science and Engineering A, 528 (2011), 3243-3248, doi:10.1016/j.msea.2010.12.103

${ }^{6}$ Y. X. Chen, J. G. Zhang, H. Wang, EBSD investigation on the anisotropy of 2124 aluminum alloy, Heat Treatment of Metals, 36 (2011) 5, 79-82, doi:10.1097/IGC.0b013e31820fa168

${ }^{7}$ W. D. Yan, G. S. Fu, G. Q. Chen, C. Z. Cheng, EBSD study on boundaries and texture of 1235 aluminum alloy affected by strain rates, Advanced Materials Research, 284 (2011), 1684-1690, doi:10.4028/www.scientific.net/amr.284-286.1684

${ }^{8}$ M. Kuroda, M. Kamaya, T. Yamada, K. Akita, Detection of fatigue damage in stainless steel by EBSD analysis (Applicability of EBSD pattern quality), Transactions of the JSME, 852 (2017), 17-00072, doi:10.1299/transjsme.17-00072

${ }^{9}$ G. Q. Chen, G. S. Fu, T. Y. Wei, C. Z. Cheng, J. D. Wang, H. S. Wang, Establishment of dynamic-recrystallization-state diagram for hot deformation of 3003 aluminum alloy, Materiali in Tehnologije/Materials and Technology, 52 (2018) 3, 341-347, doi:10.17222/mit.2017.176

${ }^{10}$ G. S. Fu, H. L. Chen, W. Z. Chen, Q. W. Qian, Observation of as-cast microstructure feature of Al sheet used for can manufacturing with high forming properties, Materials Science Forum, 3 (2007), 983-988, doi:10.4028/0-87849-432-4.983

${ }^{11}$ W. D. Yan, G. S. Fu, H. L. Chen, G. Q. Chen, Effects of oxide inclusions on flow stress behavior of 1235 aluminum alloy during hot compression, Journal of Materials Engineering and Performance, 21 (2012), 2203-2206, doi:10.1007/s11665-012-0152-0

${ }^{12}$ T. Sakai, A. Belyakov, R. Kaibyshev, H. Miura, J. J. Jonas, Dynamic and post-dynamic recrystallization under hot, cold and severe plastic deformation conditions, Prog. Mater. Sci., 60 (2014), 130-207, doi:10.1016/j.pmatsci.2013.09.002

${ }^{13}$ S. H. Kim, H. G. Kang, M. Y. Huh, O. Engler, Interpretation of the strain state during cross-roll rolling of aluminum by means of texture analysis, Materials Science \& Engineering A, 501 (2008) 1, 121-128, doi:10.1016/j.msea.2008.12.028

${ }^{14}$ C. Cayron, B. Artaud, L. Briottet, Reconstruction of parent grains from EBSD data, Materials Characterization, 57 (2006) 4-5, 386-401, doi:10.1016/j.matchar.2006.03.008

${ }^{15}$ J. Tarasiuk, P. Gerber, B. Bacroix, Estimation of recrystallized volume fraction from EBSD data, Acta Materialia, 50 (2002) 6, 1467-1477, doi: 10.1016/s1359-6454(02)00005-8

${ }^{16}$ S. O. Poulsen, E. M. Lauridsen, A. Lyckegaard, J. Oddershede, C. Gundlach, C. Curfs, D. J. Jensen, In situ measurements of growth rates and grain-averaged activation energies of individual grains during recrystallization of $50 \%$ cold-rolled aluminum, Scripta Materialia, 64 (2011), 1003-1006, doi:10.1016/j.scriptamat.2011. 01.046 